Vol. 4, No. 3, 2019

\title{
ENVIRONMENTAL DIRECTIONS OF THE TOURIST POTENTIAL DEVELOPMENT AT URBAN AGGLOMERATIONS (CASE STUDY OF THE CITY OF KYIV)
}

\author{
Margaryta Radomska, Oleksandra Kolotylo \\ National Aviation University, \\ Faculty of Environmental Safety, Engineering and Technology, \\ Department of Ecology, \\ 1, Komarov Avenue, Kyiv, 03058, Ukraine \\ m.m.radomskaya@gmail,alexsandra.kolotylo@gmail.com
}

https://doi.org/10.23939/ep2019.03.109

Received: 12.06 .2019

(C) Radomska M., Kolotylo O., 2019

\begin{abstract}
The development of urban tourism ensures preservation and expansion of valuable ecosystems and increases the level of ecological culture, which provides saving attitude to the environment. The preconditions of ecotourism development in cities are analyzed. The method for evaluation of ecotourist potential is proposed and tested on the example of Kyiv. The parameters for the selection and evaluation of the objects that can be used for ecotourism organization are considered.
\end{abstract}

Key words: ecotourism, urban ecosystem, ecological trail, ecotourism route, ecotourist potential, urban ecotourism.

\section{Introduction}

A modern city or an urban system should be regarded as a complex cluster of artificial ecotopes or a complex artificially transformed ecosystem [1]. Due to its size and structure which includes natural and manmade components of the environment on a relatively limited area, cities are "bodies" with specific regularities and functional processes [2]. The balance within these urban systems is very vulnerable and undergoes dramatic impacts and changes under the influence of industrial and life provision processes. However, the condition of the urban environment is also strongly affected by everyday activity of its citizens. Being direct users of urban natural resources, especially those providing rest and recreation (urban green infrastructure and hydrological network), humans gradually destroy the remaining components of nature which provide normal circulation of matter and energy in the cities. Thus, there is a need for a higher level of environmental awareness of urban population to set back the degradation of the environment. Besides academic approaches to environmental education through school and university curricula, ecological tourism is an important tool for distribution of knowledge about nature. However, it is primarily interested in pristine ecosystems and natural landscapes and therefore is still not very popular among the Ukrainian population: it involves distant trips to locations with low level of services and low development of infrastructure. Under such conditions in terms of the number of people involved and preservation of nature it would be more productive to organize ecological tourism inside the cities.

Ecotourism is a form of travel that focuses on preserving the natural environment, enhances the ecological culture of travelers, carries out educational functions, cares about traditions and culture and benefits the local population. It takes place at the objects with scientific, cognitive, aesthetic and recreational value. These are territories with unique natural monuments, mountains, virgin forests, mineral springs, valleys of rivers and streams, habitats of rare plants, etc. Thus, the nature-protected territories, in particular national parks, are the most promising for the development of ecotourism.

Urban territories are completely opposite to such pristine areas, but they are still strong tourist attractions. Over the last few decades cities have been considered to be habitats of living organisms and not only the living 
environment for people. The urban biocenosis is made of plant associations and zoocenosis. A wide range of flora and fauna representatives are still living here. The increased fragmentation, division and transformation of habitats, introduction of exotic and alien species and creation of artificial cultural and aesthetic components create certain ecotourism potential and it is possible to involve urban territories into specific form of ecotourism by enhancing its educational component.

Any form of tourism on urban territory will become a source of accumulating funds to maintain the normal state of the objects belonging to the recreational and tourist potential of the territory. In addition, the development of tourist potential creates working places and self-employment opportunities. If talking about ecotourism, it also supports the normal state of green infrastructure and other objects of ecological interest and raises the cultural and educational level of the urban population. Thus, the aim of the research is to define the possibilities and obstacles for the developing of ecotourism in urban areas as well as its potential content.

In order to reach the target a range of tasks should be performed: to formulate the concept of tourist potential on the whole and ecotourism potential in particular, to define the components and factors important for the development of ecotourism.

Analysis of the previous research. The idea of urban ecotourism or urban green tourism has appeared in the mid 90s with the idea of developing a sustainable way to visit urban areas [3], and obtained a clear wording during the First Urban Ecotourism Convention held in White Rock, Canada in 2004. Being in between traditional ecotourism and urban tourism, this type of touristic activity has gradually moved away from both $[3,4]$. Thus, urban tourism is more concentrated on cultural aspects of a city, while urban green tourism is targeted at natural islands preserved within the city; ecological tourism is a glance at still untouched natural zones, and urban ecotourism provides a view on the nature at the closest proximity to city dwellers, demonstrating examples of remarkable cohabitation and adaptation which are the core concepts of ecology and environmental studies.

The further development of the idea of urban ecotourism is found in the works by Dodds R. and Joppe M., Higham. J and Michael L., Vaso J. and Milosevic S., Oh J. S., Weaver D., Wu Y. Y. Most of them deal with the assessment of ecotourism potential in the cities around the world. They also note that urban ecotourism is an important direction of urban development, as it is able to support and protect residuals of nature in the city and improve living standards of the inhabitants by making the stakeholders invest into the improvement of green infrastructure, public transport optimization and maintenance of natural ecosystems and their diversity [5-8]. Some authors offer very unusual projects which involve transformation of cities to provide ultimate suitability for green tourism and sustainable lifestyle $[9,10]$.

Currently, the concept of tourist potential is used quite often in the literature. However, there is neither unified opinion on the parameters of the tourist potential as an economic system nor classification of it [11]. In most cases tourist potential is evaluated without theoretical formulation of the concept and is used for specific destinations at various levels: from localities to regions and countries. The local level is presented in the research by V. P. Pilyavskiy and O. S. Shvetsova for the Ladoga Lake [12], the work by Kulinych K. [13] deals with the regional level and evaluates the tourist potential of Sumska oblast, while Tarasionak A. and Yakovchuk O. demonstrate the tourist potential of the whole country, namely Ukraine and Belarus [14, 15].

Domestic and foreign scientists, in particular, Rudenko O. P., Drozdovym A. V., Kuskovym A. S., Arsenyeva E. I., Gulyaev V. G., Kolbovsky E. Yu. have paid attention to the problem of determining the composition of the total tourist potential of the region. Even though they bind their theories to certain types of tourism, including ecological one, they mostly work with geographical parameters which are not applicable to the analysis of ecological tourist potential of urban areas.

More generalized definition of the tourist potential is found in the works by Sviatoho N. V., Ushakova E. O., Bădiă A. and Dmytruk O. Yu., and it can be represented as a combination of natural, historical and cultural objects and phenomena, as well as social (professional and personnel potential), economic (information, financial, investment, management) and technological (infrastructure) prerequisites for the organization of tourist activities on a certain territory $[12,16,17,18]$.

A conceptually opposite approach is proposed by Jegdić V. and Gradinac O. based on the idea that ecotourism is a means for sustainable urban development: they analyze the ecotourism potential through the prism of achieving the goals of sustainability and green tourism [5]. Thus, the ecotourism potential is formed and evaluated based on the efficiency by which it provides economic (local budget benefits), social (building healthier communities, promoting local experiences) and environmental benefits (reducing energy use and raising environmental awareness) [19]. 


\section{Methods and materials}

The evaluation of local ecotourism potential should be conducted in three stages - analysis, screening and decision. The analysis includes the study of the current tourism situation, as well as environmental condition of the area under investigation. The screening is the choice of perspective ecotourism attractions and "hotspots". The final decision implies formulation and assessment of both possibilities and risks for the further development of ecotourism in the area.

These stages involve gathering, processing and interpretation of internal and external information which will output the list of priority actions to reveal the opportunities and facilities for ecotourism projects realization.

In terms of methodology, complex assessment of the territory should take into account the following groups of factors:

- natural conditions and resources (landscape structure and quality, climate, relief, hydrological objects of interest, etc.);

- level of economic development (infrastructure, services quality and necessary maintenance and investment in well-being);

- social conditions (the population interested in ecotourism, potential workplaces, level of environmental awareness and ecological education);

- environmental condition (air pollution level, water quality, soil pollution, physical pollution, biodiversity, visual pollution, etc.);

- content and aesthetic component (objects of interest for ecotourism and their educational, aesthetic and nature-preserving value);

All factors accounted in the analysis are characterized with a certain number of indicators. Most of them have ordinary units of measurements, but there are some indicators that cannot be represented this way and must first be evaluated with the grading mark system - ranking or modeling [21, $3]$. The grades are assigned to each indicator for the object under investigation and the final sum will reflect the perspective and feasibility of the project implementation.

\section{Results and discussions}

The given research is based on the following parameters chosen to characterize the suitability of urban area for the ecotourism development, and corresponding ranking from 1 to 5 (Table 1 ):

- favorability of climate conditions is evaluated based on the fact that ecological tourism means basically walking along the special route or trail which is under the influence of weather and climate;

- aesthetics of the landscapes - including aesthetic value of the relief, water objects and plant associations;

- level of infrastructure development - Internet access, reliability of mobile communication, transport accessibility.

The total score is summed up and provide the characteristics of the territory suitability for ecotourism: 40-50 is the best, 30-39 - good, 20-29 - satisfactory, $<19$ - poor). The lowest result doesn't mean that there is no point investing efforts in urban green tourism, but shows the volume of work to be performed before it is possible to acquire any payback in the form of the visitors interested in it.

The further work on the ecotourism potential analysis is the process of screening - the choice of the objects-attractions and landmarks for green tourists. According to the idea of ecotourism these are parks and forest-parks, hydrological objects, gardens and orchards which have the best nature-protected status. The objects-candidates should go through the selection process with application of the similar system, involving ranking based on the following indicators (Table 2):

- $\quad$ status of protected areas - environmental value of the ecosystem;

- level of anthropogenic transformation;

- availability of tourism information on the territory.

The objects with total score over 8 points should be included in the final project and arranged into ecological routes, provided with an information campaign and managerial support.

Once the screening is completed, the information obtained is combined with the previous stage outcomes to make the final conclusion about the ways of developing urban green tourism on the studied area and necessary investments.

The above presented method has been applied to the capital city of Ukraine for approbation and development of the ecotourism promotion plan. Kiev is very diverse and rich in natural resources. It is also called the "green city", because of a large number of parks, squares, boulevards, forest areas, as well as nature protected areas within the city. Currently, the city is being built up more and more, and territories with green plantations are reducing, the environmental situation is getting worse, increasingly affecting the health of the population. 
Evaluation of conditions suitability for ecotourism development

\begin{tabular}{|c|c|c|c|c|c|}
\hline \multirow{2}{*}{ Indicator } & \multicolumn{5}{|c|}{ Comfort level* } \\
\hline & 1 & 2 & 3 & 4 & 5 \\
\hline \multicolumn{6}{|c|}{ Climate conditions } \\
\hline $\begin{array}{l}\text { Frequency of favorable } \\
\text { weather during a year, } \%\end{array}$ & $<10$ & $10-20$ & $20-35$ & $35-40$ & $>40$ \\
\hline $\begin{array}{l}\text { The duration of the frosty } \\
\text { period, days per year }\end{array}$ & $<70$ & $70-90$ & $90-105$ & $105-120$ & $>120$ \\
\hline $\begin{array}{l}\text { The sum of active } \\
\text { temperatures over the period } \\
\text { with daily } \mathrm{t} \geq 10^{\circ} \mathrm{C},{ }^{\circ} \mathrm{C}\end{array}$ & $<800$ & $800-1400$ & $1200-1600$ & $1500-2000$ & $2000-3500$ \\
\hline $\begin{array}{l}\text { The number of days with } \\
\text { precipitations per year }\end{array}$ & $>180$ & $140-180$ & $120-140$ & $100-120$ & $<100$ \\
\hline $\begin{array}{l}\text { The average temperature in } \\
\text { July, }{ }^{\circ} \mathrm{C}\end{array}$ & $\begin{array}{l}\geq 21.6 \\
\leq 17.4\end{array}$ & $\begin{array}{l}21.1-21.5 \\
17.9-17.5\end{array}$ & $\begin{array}{l}20.6-21 \\
18.4-18\end{array}$ & $\begin{array}{l}20.1-20.5 \\
18.9-18.5\end{array}$ & $19-20$ \\
\hline Overall description & $\begin{array}{l}\text { Favourable } \\
\text { conditions for } \\
1-2 \text { months: } \\
\text { short cool } \\
\text { summer and } \\
\text { long winter or } \\
\text { hot summer and } \\
\text { snowless } \\
\text { winter. }\end{array}$ & $\begin{array}{c}\text { Favourable } \\
\text { conditions for } \\
\text { less than } 3 \\
\text { months: hot } \\
\text { droughty } \\
\text { summer and } \\
\text { unstable winter } \\
\text { with little snow } \\
\text { cover or } \\
\text { without it }\end{array}$ & $\begin{array}{c}\text { Favourable } \\
\text { conditions for } \\
3-6.5 \text { months: } \\
\text { cool rainy } \\
\text { summer and } \\
\text { mild winters } \\
\text { with unstable } \\
\text { snow cover or } \\
\text { hot drought } \\
\text { summer and } \\
\text { rigorous winter }\end{array}$ & $\begin{array}{c}\text { Favourable } \\
\text { conditions for } \\
\text { 7-9 months: hot } \\
\text { and dry summer } \\
\text { and mild winter } \\
\text { with stable } \\
\text { snow cover }\end{array}$ & $\begin{array}{c}\text { Favourable } \\
\text { conditions for } \\
9,5-10,5 \text { months: } \\
\text { warm summers } \\
\text { and moderately } \\
\text { cold winters with } \\
\text { stable snow cover } \\
\text { or hot long } \\
\text { summer and short } \\
\text { warm winter } \\
\text { without stable } \\
\text { snow cover }\end{array}$ \\
\hline \multicolumn{6}{|c|}{ Relief value } \\
\hline Altitude & $1000-2500$ & 2500 & $0-100$ & $100-400$ & $700-1000$ \\
\hline Type of relief & Alpine & Alpine & Flat & $\begin{array}{c}\text { Hilly, low } \\
\text { mountain }\end{array}$ & $\begin{array}{c}\text { The average } \\
\text { mountain }\end{array}$ \\
\hline \multicolumn{6}{|c|}{ Water bodies value } \\
\hline Type of waterbody & Absent & $\begin{array}{l}\text { Stream or } \\
\text { source }\end{array}$ & Major river & Lake & $\begin{array}{c}\text { The average river } \\
\text { with rushes / } \\
\text { waterfalls }\end{array}$ \\
\hline \multicolumn{6}{|c|}{ Plant association value } \\
\hline Type of biocenosis & Desert & Steppe & Meadow & Forest & Forest - steppe \\
\hline
\end{tabular}

* Note: 1 - not suitable; 2 - low value; 3 - medium-comfortable; 4 - comfortable; 5 - most favorable.

Table 2

Evaluation scale for screening

\begin{tabular}{|l|c|c|c|c|c|}
\hline \multirow{2}{*}{ Indicator } & \multicolumn{4}{|c|}{ Suitability for ecotourism* } \\
\cline { 2 - 6 } & 1 & 2 & 3 & 4 & National \\
\hline Protected area status & Not defined & Local & Regional & International \\
\hline $\begin{array}{l}\text { Level of anthropogenic } \\
\text { transformation }\end{array}$ & $\begin{array}{c}\text { Badly preserved } \\
\text { and heavily } \\
\text { modified } \\
\text { natural or new } \\
\text { artificial } \\
\text { recreational } \\
\text { object }\end{array}$ & $\begin{array}{c}\text { Artificial } \\
\text { landscape with } \\
\text { certain aesthetic } \\
\text { value }\end{array}$ & $\begin{array}{c}\text { Strongly } \\
\text { transformed for } \\
\text { the visitors' } \\
\text { comfort or } \\
\text { artificial } \\
\text { plantations (over } \\
50 \text { years old) }\end{array}$ & $\begin{array}{c}\text { Marginally } \\
\text { transformed for } \\
\text { the improved } \\
\text { access or old } \\
\text { artificial } \\
\text { plantations } \\
\text { (over 100 years) }\end{array}$ & Pristine \\
$\begin{array}{c}\text { Availability } \\
\text { information on the territory }\end{array}$ & $\begin{array}{c}\text { No information } \\
\text { is available }\end{array}$ & $\begin{array}{c}\text { Information is } \\
\text { available over } \\
\text { the Internet or } \\
\text { at local } \\
\text { authorities }\end{array}$ & $\begin{array}{c}\text { Single } \\
\text { information } \\
\text { sign at one } \\
\text { point }\end{array}$ & $\begin{array}{c}\text { Information } \\
\text { signs and route } \\
\text { markers are } \\
\text { available }\end{array}$ & $\begin{array}{c}\text { Information signs } \\
\text { and route markers } \\
\text { are available, } \\
\text { guided tours are } \\
\text { offered }\end{array}$ \\
\hline
\end{tabular}

* Note: 1 - supplementary object; 2 - low value; 3 - suitable; 4 - most suitable; 5 - core value. 
To improve the environmental situation in the city, in 2014 the Kyiv city state administration issued the project "Environmental policy of the Kyiv city for the period until 2025", where it is indicated, that one of the main measures in implementing the system of environmental culture and development of ecological education in the city can be creation and equipment of ecological routes on the territories of natural, natural-historical and landscape parks, nature reserves and nature monuments. Also, ecological routes are mentioned in the point on managing the greenery [21].

The ecotourism potential of Kyiv has been evaluated as a good one with the total score of 38 points. The result shows that the territory of Kyiv is suitable and satisfactory, and has good conditions for the development of tourist activity. For additional testing the offered method was applied to evaluate the potential of the cities, currently being actively involved in the corresponding projects abroad. Thus, the grade of Novi $\mathrm{Sad}$ is 36 , based on the data obtained from the open sources and [5], Seoul has 42, as it can be concluded on the shared information and [22]. So, the method is quite representative and detailed to reflect the actual situation.

The screening process for Kyiv has produced a list of more than 70 potential ecotourism objects which have been arranged into the ecological routes. It is worth mentioning that there is a range of obstacles for the formation of ecological trails: close interaction between natural and technogenic objects, limited access to certain areas, low quality of infrastructure and inefficient maintenance (problems with waste management) and lack of information distributed.

However, in order to increase the educational component of ecological routes, it is recommended to include some technogenic objects into their plan. The tourists should see the contrast between the elements of wildlife and objects artificially created or highly transformed by people. Thus, people can realize the intensity of the negative impact of our society on the environment, the intensity of degradation of natural complexes under the urban conditions and get acquainted with real examples of environmental problems which actually are located almost at their houses. For this purpose, the route should run from parks and objects of the nature reserve fund on the territory of the city to enterprises or anthropogenically altered landscapes.

The example such route will include the following points:

1. Park "Peremoha" - a park with well developed infrastructure for recreation, military monuments, panoramic view on the capital's left bank, and a natural monument - a group of trees of Fagus sylvatica (forest beech). It is also an area of high bird diversity and a habitat of water mammals.

2. Lake Radunka is a good example of community activity: it has been granted the status of the Landscape Reserve of local value in 2017 under the pressure of non-governmental organizations and local citizens. It is a habitat of plants, included into the Red Book of Ukraine: Salvinia nátans and Trapa nátans.

3. The Verbniaky and Sytniaky tracts are historic, partly wild places near the river Desenka which have been mentioned in Kyiv history since XI century. The avifauna of these localities is quite rich and represents not only aesthetic but also scientific and protection interest. Similarly, local plant associations, which have the character typical for this territory before the beginning of active urbanization, are of high interest.

4. Lake Hnylusha is considered to be one of the most dangerous water reservoirs in Kiev due to heavy pollution. There is a memorial sign next to the lake: here Yaroslav the Wise concluded a peace agreement with his brother, which contributed to the unification of Ukraine-Russ into a single state in 1020.

The length of the route is about $8-9 \mathrm{~km}$, duration of the walking tour is about 3 hours.

The Left Bank of the Kyiv city is richer in natural and pristine objects, so the first set of ecological routes has been developed for the given part of the city. It includes 5 routes with 33 points; average duration of the walking tour is $2.5-3$.

To start efficient exploitation of ecotourism potential it is necessary to invest in the development of the infrastructure, namely purchasing of electric buses/bicycles (for tourists), training of guides and their fee, information distribution means and sanitary facilities. The total sum for these routes (management and implementation of which should be centralized) makes up about $510000 \mathrm{UAH}$. The calculation is approximate because most of the services have a wide range of prices. Despite the considerable financial costs, urban ecotourism is a necessary activity as it will have positive influence on ecological awareness of the population and encourage people to invest their efforts in support of natural components of the city thus supporting the environment quality in their city.

At the same time it is important to take into account the vulnerability of natural islands suitable for ecotourism development, as these formations are under heavy pressure from the urban artificial components. Thus, an important precondition for successful implementation of the project is determination of permissible recreational pressure on the areas involved, which is the next step for the research. 


\section{Conclusions}

1. The environmental balance in the cities is very vulnerable to technogenic pressure from the industrial facilities and anthropogenic impacts of the population using its resources without any environmental reservations. The improvement of environmental awareness of city dwellers is a key to mitigation of urban environment degradation. This task could be performed by the development of ecological tourism at the territory of cities which should be considered from the point of the value of their landscapes, phytocenosis and zoocenosis components.

2. The concept of ecotourism potential is widely used but it is poorly provided with theoretical background as well as methods of its assessment. For the purpose of the given research the method of ecotourism potential assessment has been developed and applied to a range of cities. Screening of suitable attractions has been completed for the city of Kyiv.

3. To promote ecotourism in Kyiv, a project of ecological routes was developed and the amount of investment in their infrastructure development was calculated. The need for regulation of the number of eco-tourists is formulated as a necessary component for the organization of urban green tourism.

4. The development of environmental tourism in Ukraine will have positive influence on the development of ecological consciousness among the local population and contribute to preservation of nature islands in the cities.

\section{References}

[1] Y. Didukh, U. Alioshkina : Ecotope Classification Of Kyiv : NaUKMA Research Papers. Biology and Ecology. 2006, Vol. 54, 50-57. (In Ukrainian)

[2] Niemelä J., Breuste J. H., Guntenspergen G., McIntyre N. E., Elmqvist T., James P. : Urban Ecology: Patterns, Processes, and Applications. Oxford, UK: Oxford University Press, 2011. 392 p.

[3] Wu, Y. Y., Wang H. L., Ho Y. F.: Urban Ecotourism: Defining and Assessing Dimensions Using Fuzzy Number Construction: Tourism Management, 2010, 31(6), 739-743. DOI: 10.1016/j.tourman.2009.07.014.

[4] Vaso, V., Milošević, S.:Urban Ecotourism as a Mean of Sustainable Development of Cities: Proceed. of XV International Eco-conference: Environmental Protection of Urban and Suburban Settlements II, Novi Sad, Serbia, 2011, 433-441.

[5] Vaso J., Gradinac, O.: Cities as destinations of urban ecotourism: The Case Study of Novi Sad. Acta Economica Et Turistica, 2016, Vol 2 No. 2, 101-236. DOI: $10.1515 /$ aet-2016-0014

[6] Higham, J., Lück, M.. Urban Ecotourism: A Contradiction in Terms? : Journal of Ecotourism, 2002, 1:1, 36-51. DOI: 10.1080/14724040208668111.

[7] Weaver, D., Lawton, L.: Twenty years on: The state of contemporary ecotourism research. Tourism
Management, 2007, 28, 1168-1179. DOI:10.1016/ j.tourman.2007.03.004.

[8] Gibson, A., Dodds, R., Joppe, M., Jamieson, D.: Ecotourism in the city? Torontos Green Tourism Asociation. International Journal of Contemporary Hospitality Management, 2003, 15(6), 324-327.

[9] Tham, A.: Envisioning Eden: the manufactured ecotourism environment of Singapore: Journal of Ecotourism, 2018, 17:3, 287-305. DOI: 10.1080/14724049.2018.1502124.

[10] Demir, S., Atanur, G.: The prioritization of naturalhistorical based ecotourism strategies with multiplecriteria decision analysis in ancient UNESCO city: Iznik-Bursa case: International Journal of Sustainable Development \& World Ecology, 2019, 26:4, 329-343. DOI: $10.1080 / 13504509.2019 .1596990$.

[11] Svyatokha, N. Yu., Filimonova, I. Yu., Yakovlev I. G.: Ecotourism as a form of rational recreational nature management (on the example of the Orenburg region). Bulletin of the Orenburg State University, 2016, 8 (196), 70-75. (in Russian)

[12] Pilyavsky V. P.: Evaluation of the tourist and recreational potential of the territory of the Ladoga area. Bulletin of Donetsk Institute of Tourist Business. Series: Economics, organization and management of the tourist industry and tourism in the whole, 2014, 18, 66-70. (in Russian)

[13] Kulinich, K. M.: Ecological tourist product and mobility to ecotourism in Sumy region: Proceed. of the International scientific conference Economical problems of steel development, to the memory of prof. Balatskogo O. F. Sumy, Ukraine, 2013, 84-85. (In Ukrainian)

[14] Yakovchuk, O. V.: Assessment of tourist potential of Ukraine: Geography and tourism, 2010, 10, 57-65. (In Ukrainian)

[15] Tarasionak, A.: Strategic planning of tourist destinations: new approach towards territorial organization of tourism in Belarus: Geografijos metraštis, 2014, 47, 25-36. (In Russian)

[16] Ushakova E. O.: Methodical approach to the integrated assessment of tourism development resources in the region. Regional Economics: Theory and Practice, 2013, 48, 42-49. (In Russian)

[17] Bădiță, A. Approaches to the analysis and evaluation of urban tourism system within urban destinations. Journal of Tourism, 2013, 16, 58-66.

[18 ] Dmitruk O. Yu.: Ecological tourism: modern concepts of management and marketing. Alterpres, Kyiv 2004. 192 c. (In Ukrainian)

[19] Butty, A., Berclaz, J., Pfefferlé, M., Maret, J.: Urban Ecotourism: How Urban Tourism Could Be Sustainable and Environmentally Friendly? Haute Ecole de Gestion \& Tourisme, Valais, France, 2014. 13 p.

[20] Khodiko, DI, Kriven, O. V.: Formation of the grade assessment of the recreational potential of territories: Regional economy, 2015, 4. 81-89. (In Ukrainian)

[21] Environmental policy of the city of Kyiv for the period up to 2025: Kyiv City State Administration, Kiev 2015. 24 c. (In Ukrainian)

[22] Oh, J.S.: Urban Ecotourism: Applying Natural Ecological Resources to Tourism in Seoul, Korea : Binghamton University, New York 2007. 21 p. 